\title{
Significant Intersections between Legal and Rhetorical Theories: Lessons from an Interdisciplinary Reading of al-Bāqillānī's Theory of Language
}

\author{
RACHEL ANNE FRIEDMAN (Williamstown, Williams College)
}

\begin{abstract}
Abū Bakr al-Bāqillānī (d. 403/1013) was a preeminent scholar and an influential participant in a diverse range of Islamic discourses including the Ash'arī school of theology and the Mālikī school of law. AlBāqillān̄̄'s texts are often studied within the context of individual disciplines, but this article demonstrates that an interdisciplinary reading of his scholarly production uncovers significant areas of overlap. These intersections bring to light topics of sustained concern for al-Bāqillānī that crosscut his work and allow him to draw together various Islamic intellectual discourses. Through looking at three such intersections, on the topics of bayān, muhkamāt and mutashābihät, and the so-called Mysterious Letters, this article shows that al-Bāqillānī's argument in favor of the clarity and eminent understandability of language, including all of the Qur'ān, is best understood through a cross-disciplinary reading of al-Bāqillānī's oeuvre. Bringing together al-Bāqillānī’s thought in the two seemingly disparate genres of ușūl al-fiqh (legal theory) and $i$ jāz al-Qur'ān (the inimitability of the Qur'ān) serves the dual purpose of examining the relationship between these fields and shedding light on al-Bāqillān̄̄s work across disciplines. It thus contributes to a more complete picture of the identity of a scholar who was concerned with providing a consistent and multifaceted theory of language within a broader synthesis of Islamic thought.
\end{abstract}

Key words: Language, al-Bāqillānī, ușūl al-fiqh, i jāaz al-Qur'ān, bayān, interdisciplinary

\section{Introduction}

This article explores the intellectual contribution of Abū Bakr al-Bāqillānī (d. 403/1013), a preeminent scholar who was an influential participant in a diverse range of Islamic discourses. ${ }^{1}$ Famous for his wide-reaching impact on the Ash'arī school of theology and the Mālikī school of law, al-Bāqillānī authored a body of work that has proved difficult for scholars to conceptualize and characterize as a whole, due not only to its participation in

1 This article is based on findings that emerged from my dissertation. For a more detailed discussion see my dissertation, "Clarity, Communication, and Understandability: Theorizing Language in al-Bāqillān̄̄'s Ijāaz al-Qur'ān and Ușūl al-Fiqh Texts" (FrIEDMAN 2015), which I am currently revising as a monograph. 
diverse specialized disciplines, but also to the circuitous structure of al-Bāqillān̄̄'s texts. ${ }^{2}$ Extant studies contextualize and analyze aspects of specific books that al-Bāqillānī composed without bringing into view his broader scholarly identity and contribution. This article begins the work of offering a corrective to previous atomistic studies of his texts. It does so by bringing together al-Bāqillān̄̄'s writings in two seemingly disparate fields, $u s ̣ \bar{u} l$ al-fiqh (jurisprudence) and $i{ }^{\prime} \bar{a} z$ al-Qur'ān (inimitability of the Qur'ān), highlighting important areas of overlap and intersection. It analyzes the ways in which these texts express al-Bāqillān̄̄'s theory of language, a central topic in his thought, devoting particular attention to his understanding of the roles of rhetoric and figurative language. It also demonstrates how al-Bāqillānī's sustained attention to some topics across his writings allows him to consistently express his own theological and exegetical interventions. One central point that comes to the fore through extensive readings of al-Bāqillānī's texts is his assertion of a unique vision of the Qur'ān as miraculously clear and understandable to humans even as it expresses divine meanings in language that humans could never successfully imitate.

Reading al-Bāqillānī’s texts in these discourses with particular attention to their thought on language, broadly conceived, is far from a narrowly thematic undertaking. Rather, the implications of how to understand the ways in which language works permeate the central questions of classical Islamic scholarship at large and occur across disciplinary boundaries. Medieval Islamic scholars were acutely aware of these implications, and their discussions resulting from this awareness are found in a variety of fields of intellectual inquiry. Though writings on the Qur'ān's rhetorical excellence and Islamic legal theory are conventionally studied separately from one another, they both address larger language-related questions. In fact, both of these discourses dealt at length with the questions of how to understand Qur'ānic language in relation to humans' utterances and how to properly interpret both of these types of language usage. Scholarship undertaken in the last few decades has investigated the ways in which individual disciplines addressed such questions in the classical eras of Islam, with the fields of balāgha (rhetoric) and ușūl al-fiqh (jurisprudence) constituting primary (but separate) areas of inquiry. Modern scholarship has emphasized that in the realm of balāgha and particularly in its Scripturally-centered valence of $i j \bar{a} z$ al-Qur'ān (the inimitability of the Qur'ān), classical scholars generally investigated language for its aesthetic qualities, though later developments in the field, led by 'Abd al-Qāhir al-Jurjānī (d. 1078), developed a rhetorical theory of the relationship between grammar and meaning. ${ }^{3}$ Meanwhile, a recent spate of attention has been given to theories of linguistic communication in Islamic legal theory, particularly ideas regarding the correct ways of interpreting Qur'ānic verses and humans' utterances in order to determine their legal force and its scope. ${ }^{4}$ Although those two fields still constitute separately treated realms of thought, other studies that are mindful of interdisciplinary connections have affirmed the importance

2 Al-BĀQILLĀNİ's texts often circle back to the same topics in multiple sections, thus rendering it difficult to determine his overarching concerns or attitude toward a particular issue based on discrete sections of the texts.

3 'Abd al-Qāhir al-JURJĀNII's two celebrated treatises are Asrār al-balāgha (ed. SHĀKIR 1991) and Dalāill al-ijäz (ed. SHĀKIR 1995). For more on al-Jurjānī's approach and its influences, see LARKIN 1988: 31-47. In the field of balägha, see HEINRICHS 1984: 180-211.

4 See Gleave 2012; Vishanoff 2011; Weiss 1992. 
of looking beyond the boundaries of genre. For example, scholarly efforts to account for the effects of different intellectual fields and currents of thought on rhetorical theories that were developed during the late $3^{\text {rd }} / 9^{\text {th }}$ century and the $4^{\text {th }} / 10^{\text {th }}$ century have demonstrated the fruitfulness of such approaches. ${ }^{5}$ It has become clear that concerns central to the intellectual milieu crosscut disciplinary boundaries in interesting ways, and that there was an especially close connection between linguistic and theological endeavors. Understanding these dynamics in turn broadens scholarly understanding of each discipline and the ways in which its constituent discussions related to other realms of Islamic thought.

An even more strongly comparative approach can shed light on the relationships between $i j \bar{a} z$ al-Qur'ān and ușül al-fiqh, both Islamic discourses par excellence. This type of approach can also help answer questions of an essentially interdisciplinary nature. For example, how consistent were theories of language across these disciplines? Can interdisciplinary investigations of a concept such as language provide a more robust understanding of how medieval Islamic thinkers understood that concept and their world more broadly? Wolfhart Heinrichs pointed to the potential insights of such an investigation when he called for a study of majāz (roughly, figurative language) as it developed in ușul al-fiqh in order to shed light on a concept that had been studied mostly through the lens of balaggha but was operative in ușul al-fiqh as well. ${ }^{6}$ Though Heinrichs suggested this project more than twenty years ago, the gap between study of those two fields remains, and little has been added to the discussion of how useful it would be to study relationships in thought between two such apparently separate fields.

Though there are many possible starting points to investigate such questions of the relationships between disciplines, I have chosen to take the work of Abū Bakr Muhammad ibn al-Ṭayyib al-Bāqillānī as an entrance point into this direction of study. Al-Bāqillānī was considered the most prominent Ash'arī theologian of his day and studied under the students of al-Ash'arī himself. He was also a famous Mālikī jurist and legal theorist. Because he authored books in both uṣūl al-fiqh and i ijäz al-Qur'än (among numerous other fields), he is an ideal subject for a comparative case study of the ways in which one thinker approached and theorized language in two fields. ${ }^{7}$ If a comparison of legal and rhetorical discourse were to center on different authors, it would be difficult to determine whether significant divergences in terminology and theory of language were due to generic or disciplinary differences, or rather to other factors such as theological or legal school affiliation, regional ethos, chronological developments, personal background, and individual taste. A

5 Wolfhart Heinrichs has described the dynamics between the study of linguistic expression and other Islamic endeavors. Margaret Larkin has demonstrated the theological underpinnings of 'Abd al-Qāhir al-Jurjānī's work on Qur'ānic inimitability and figurative language, while Alexander Key's study on alRāghib al-Ișfahānī (d. 502/1108) has examined the relationship between a theory of language and its ambiguities and diverse fields including exegesis, poetry, and theology. HEINRICHS 1984: 111-140 and 1977; LARKIN 1995; KEY 2012.

6 HEINRICHS 1977: 53.

7 Other topics on which al-Bāqillānī authored books include theology, miracles, political and religious leadership, intra- and interreligious polemic, divine attributes and characteristics, free will, physical theories, and morals and virtues. For more on his intellectual formation and production, see IBISH 1965: 226-29. 
study of al-Bāqillānī's thought in two important realms has the additional benefit of contributing to current understandings of al-Bāqillān̄̄'s thought and intellectual identity. This comparative study of al-Bāqillān̄̄'s work in uṣūl al-fiqh and ijāz al-Qur'ān uncovers the ways in which important themes in al-Bāqillānī's work reemerge in different forms across genres. It also discovers a cohesive scholarly identity and vision that al-Bāqillān̄i maintained in the various theological discourses in which he engaged.

Now is an opportune moment to revisit al-Bāqillān̄̄ss scholarship, because more of his works are available for study than were to earlier generations of modern-era scholars. In recent decades, books previously thought to be lost have been discovered in manuscript form, and many of them have subsequently been published. The incremental discovery of al-Bāqillānī's texts has allowed for further insight into his thought and also encourages the continual revisiting of each text in light of newly discovered ones. Abdul Aleem wrote in 1933 that al-Bāqillān̄̄'s book on $i{ }^{\prime} j \bar{z} z$ al-Qur'ān was his only preserved work. ${ }^{8}$ As recently as 1952, Philip Hitti wrote that al-Bāqillānī only had two surviving works. ${ }^{9}$ In 1959, Johan Bouman only had access to three of al-Bāqillānī's works and believed them to be the only extant ones: Kitāb I'jāz al-Qur'ān, al-Tamhīd, and al-Inșāff, described below. ${ }^{10}$ The medieval bio-bibliographer Q āọ̄ 'Iyād and $20^{\text {th }}$-century Islamicist Yusuf Ibish both provide lists of al-Bāqillānī's work (including texts no longer available) that were in turn compiled from earlier bio-bibliographical sources. ${ }^{11}$ Most of the books they list are not known to be extant today, but many are widely attested in other medieval authors' writings. The following list comprises al-Bāqillānī’s books that are proven to be extant today:

1. Hidāyat al-mustarshidīn [Guide for Those Seeking the Right Way], a comprehensive multi-volume work covering diverse theological matters; ${ }^{12}$

2. Kitāb I'jāz al-Qur'ān [Book on the Inimitability of the Qur'ān], an investigation of the Qur'ān's stylistic excellence, particularly in comparison to poetry; ${ }^{13}$

3. Al-Inșâf fì-mā yajib al-itiqāad wa-lā yajūz al-jahl bihī [The Just Treatment of What It Is Necessary to Believe and about Which One May Not Be Ignorant], a book of theological doctrines and discussion of the ways through which their truths are knowable; $^{14}$

4. Nukat al-intișār li-naql al-Qur'ān [Remarks on the Victory of the Qur'ān's Transmission], on aspects of the Qur'ān concerning rhetoric, language, exegesis, and transmission; ${ }^{15}$

\footnotetext{
8 ABDul AleEm 1933: 75.

9 HiTTI 1952: 146.

10 BOUMAN 1959: 57.

11 IBISH 1965: 226-29; 'IYĀD, Tartīb: 601-02.

12 Excerpts have been found in recent years. See GIMARET 2009: 259-313; SCHMIDTKE 2011: 39-71.

13 Ed. Ahmad ȘAQR, Cairo: Dār al-Ma‘̄āif, n.d.

14 Ed. Muḥammad Zāhid al-KAWTHARĪ, [Cairo]: Mu’assasat al-Khānj̄̄i, 1963.

15 Ed. Maḥmūd Zaghlūl SALLĀM, Alexandria: Munsha’āt al-Ma‘āiif, [1971?].
} 
5. Al-Intișār lil-Qur'ān [Victory Belongs to the Qur'ān], a defense of theological doctrines surrounding the Qur'ann and its proper recitation; ${ }^{16}$

6. Manāqib al-a'imma al-arba'a [The Merits of the Four Imams], lauding the four Rightly Guided Caliphs and defending their right to authority; ${ }^{17}$

7. Kitāb al-Bayān 'an al-farq bayn al-mu'jizāt wa'l-karamāt wa'l-hiyal wa'l-kahāna wa'l-sihrr wa'l-nārinjāt [introduced and published by Richard Joseph McCarthy under the title Miracle and Magic: A Treatise on the Nature of the Apologetic Miracle and Its Differentiation from Charisms, Trickery, Divination, Magic and Spells], on miracles generally and the Qur'ānic miracle in particular; ${ }^{18}$

8. Ikfär al-muta'awwilīn [Accusing the Interpreters of Unbelief], a sectarian polemic; ${ }^{19}$

9. Tamhīd al-awāìl wa-talkhīs al-dalāill [The Introduction of the Primary Premises and Summary of the Indicants $],{ }^{20}$ which constitutes the first comprehensive laying out of Ash'arī theological doctrine;

10. Al-Taqrīb wa'l-irshād fì ușül al-fiqh [Proximity and Guidance on the Roots of Law], a text of legal theory;

11. Al-Ușül al-kabìr fì 'l-fiqh [The Large Book of Roots of Fiqh], also on legal theory. ${ }^{22}$

The study of al-Bāqillānī's oeuvre is uniquely charged with potential insights into the intellectual landscape in the formative $4^{\text {th }}-5^{\text {th }}$ centuries AH $\left(10^{\text {th }}-11^{\text {th }}\right.$ centuries CE) because alBāqillānī participated in so many different discourses and, I argue, demonstrated a keen interest in synthesizing these discourses in order to construct an internally consistent conception of Islamic doctrine and thought. The relationship between various scholarly disciplines was undergoing change during al-Bāqillānī's lifetime. The movement toward systematization in both jurisprudence and Qurānic inimitability during that momentous time in the history of Islamic thought reflects the larger ethos of this period and its concern with conceptualizing and defending Arabo-Islamic heritage and ideology. ${ }^{23}$ One contentious focal point of theological discussions, broadly construed, was the identification and inter-

16 Ed. 'Umar Ḥasan al-QAYYĀM, 2 vols., Beirut: Mu’assasat al-Risāla, 2004; ed. Muhamammad 'Ișām alQUḌ̄T, 2 vols., Beirut: Dār Ibn Hazm, 2001. The latter edition includes a preface by the editor differentiating Nukat al-intișār li-naql al-Qur'ān from al-Intișār lil-Qur'ān.

17 Ed. Samīra FARAH̄î̄, [n.p.]: Dār al-Muntakhab al-'Arabī, 2002.

18 Introduced by Richard Joseph MCCARTHY in his edition under this title: Miracle and Magic $=$ Kitāb al-bayān: A Treatise on the Nature of the Apologetic Miracle and its Differentiation from Charisms, Trickery, Divination, Magic and Spells, Beirut: Librairie Orientale, 1958.

19 Ed. Cairo: Machad al-Makhțūtāt al-'Arabiyya, 2006.

20 Ed. Mạ̣mūd Muḥammad al-Khup̣ayrī and Muḥammad 'Abd al-Hādi Maḥmūd ABŪ Rip̣Ā, [Cairo]: Dār al-Fikr al-'Arabī, [1989?]. Also known as al-Tamhīd fì 'l-radd 'alā 'l-mulhida al-mu'atțila wa'lräfida wa'l-khawārij wa'l-mu'tazila.

21 Ed. 'Abd al-Ḥamīd ABū ZunAYD, 3 vols. (1993), repr. Beirut: Mu’assasat al-Risāla, 1998. Also known as Al-Taqrīb wa'l-irshād fi tartīb turuq al-ijtihād [Proximation and Guidance in Organizing the Ways of Independent Legal Reasoning].

22 Sections of this manuscript have reportedly been discovered at al-Azhar, see ZAKĪ 2012.

23 See Ahmed El Shamsy 2013; Scott C. LuCAS 2004: 2-9. 
pretation of figurative language in the Qurān, especially in connection with debates about anthropomorphism of the Divine.

Before turning my attention to significant points of intersection and dialogue between al-Bāqillānī's work in the fields of ușūl al-fiqh and i 'Gäz al-Qur'ān, I will introduce the available text that al-Bāqillānī composed in each of those disciplines. A full-fledged review of scholarship on these treatises is outside the scope of this article, but a brief summary of how they have been approached and analyzed will provide important insight into how they have generally been received and studied so far. Starting with al-Bāqillānī’s work on $u s ̦ u \bar{l} l$ al-fiqh, his only extant and published text in this discipline is entitled al-Taqrīb wa'l-irshäd fi ușül al-fiqh (Proximation and Guidance on the Roots of Law). That book, to which I will henceforth refer as the Taqrîb, is also one of the earliest available treatises of ușül al-fiqh. The textual record indicates al-Bāqillānī authored multiple books in the ușül al-fiqh genre, but the Taqrîb is the only one that has survived and been published (if only in part, as explained below). Bibliographies of al-Bāqillānī's works tell us that he authored three different versions of the Taqrïb: a long one, a mid-length one, and a short one. ${ }^{24}$ In 1993, 'Abd Allāh al-Ḥamīd b. 'Alī Abū Zunayd published and edited a three-volume set that according to Abu Zunayd comprises the first of two volumes of the short version of the Taqrīb, which he produced using a manuscript found at the Hyderabad State Library and marked as being the first of two volumes. Unfortunately, the second volume was not found, and no other copies of the manuscript are known to exist. ${ }^{25}$ Large sections of the Taqrīb focus on issues related to language, among which are discussions concerning the means by which language communicates, ways of soundly discerning meanings in it, and a framework for understanding the relationship between Qurānic and human-authored language. Al-Bāqillānī focuses his discussions around methods of obtaining clear understandings of meaning at the levels of the word and the utterance.

In the Taqrīb, I argue, al-Bāqillānī interprets and redefines hotly debated elements of the Qur'ānic lexicon and Islamic discourse, such as bayān, muhkam, mutashābih, and the so-called Mysterious Letters (al-hurüf al-maqatta'a) in ways that support his vision of Qur'ānic and human language use. Al-Bāqillān̄’s definitions and discussions of these keywords contribute to the assertion of a particular, theologically attuned view of language, scripture, and interpretability. He develops a multifaceted argument, over the course of this treatise, that all language, even figurative language, is systematically comprehensible according to rules. He emphasizes the communicativity of language and the understandability of the Qur'ān. These discussions have been a particular focus of recent scholarly attention. Robert Gleave has given attention to the Taqrīb in his book Islam and Literalism, focusing on two sections of al-Bāqillānī's text, entitled by the editor as 'Divisions of communicative speech' and 'Knowing the difference between haqīqa and majāz. ${ }^{26}$ David Vishanoff has also discussed al-Bāqillānī's legal theory with particular reference to linguistic interpretation in a chapter of his dissertation, published in revised form as The Formation of Islamic

24 IYĀḌ, Tartīb: 601.

25 'Abd al-Ḥamīd ABŪ ZunAYd, “al-Qism al-dirāsī,” in al-BĀQILlāñ̄, Taqrīb (ed. Abū Zunayd) 1998: 91.

26 GLeave 2012: 116-20.

$J A I S \cdot 16$ (2016): 99-123 
Hermeneutics: How Sunni Legal Theorists Imagined a Revealed Law. ${ }^{27}$ Gleave's and Vishanoff's contributions are important starting points for understanding al-Bāqillān̄̄'s and other $u s ̦ u \bar{l} \overline{\mathrm{s}}$ ' (jurisprudents') theories of language and for integrating their work into the narrative of historical development within the field of Islamic legal theory. Their thematic focus on the ways in which medieval Islamic legists determined the pragmatic qualities of utterances (to be literal, figurative, ambiguous, etc.) is an important point of departure for interdisciplinary study of Islamic semantics and pragmatics as well as wider intradisciplinary studies of Islamic legal theory.

Turning to al-Bāqillān̄̄'s work on Qur’ānic inimitability, al-Bāqillān̄̄'s text known simply as Kitāb Ijāz al-Qur'ān [The Book of the Qur'ān's Inimitability] is considered a classic work on the subject. ${ }^{28}$ Past scholarship has consistently focused on a subset of the sections and themes the text includes. While providing important insights about alBāqillānī's approach, this scholarship's selective emphasis and decontextualization of discrete points in the text has led to a limited understanding of his view of the phenomenon of $i j \overline{j a} z$ al-Qur'ān. To be more precise, existing scholarship on al-Bāqillānī's $i{ }^{\prime} j \bar{a} z$ work tends to highlight arguments he made that eventually became components of the normative Islamic doctrine of the Qur'ān's literary inimitability, ${ }^{29}$ but scholars have focused their detailed attention on al-Bāqillānī's treatment of rhetorical figures and poetry. ${ }^{30}$ They have attended to his long chapter cataloguing $b a d \tau^{-}$(roughly understandable as 'literary devices') in the conventional genre established by Ibn al-Muttazz and continued by scholars after him, as well as al-Bāqillān̄̄'s extended literary analysis of poems by Imru' al-Qays and Abū Tammām. These sections of al-Bāqillānī's book differentiate it from previous $i^{i} j \bar{j} z$ texts that had not delved so deeply into the realm of the literary or carried out the detailed work of 'demonstrating' the Qur'ān to be superior to poetry based on literary analysis. However, the parts of the text that do not fit easily into a conception of the text as literary critical in nature have gotten far less attention. ${ }^{31}$ By dwelling almost exclusively on these parts of the text, which are overtly focused on the literary, secondary scholarship perpetuates a conception of the text as a contribution to literary critical history. It is more accurate to characterize al-Bāqillān̄̄'s $i j \bar{a} z$ text as a scholarly contribution to theology that interfaces with exegetical theory and literary criticism, as my analysis below indicates.

Bringing together al-Bāqillānī's thought in these two different genres serves the dual purpose of constituting a case study in the ways in which thought in each of those disci-

27 VISHANOFF 2011.

28 Sophia Vasalou, for example, includes his Kitāb Ijāzz al-Qur'ān in the "seminal works" on i ijāz composed in the 10th century (VASALOU 2002: 24). Abdul Aleem says "Bâqillânî's book is reported to be the best ever written on the subject" (ABDUL ALEEM 1933: 75). He also claims it was "the basis for all those who wrote on the subject later" (ibid.: 77).

29 These 'canonical' points include the ideas that the Arabs were all unable to meet the Qur'ân's so-called Challenge Verses ( $\bar{a} y \bar{a} t$ al-tahadd $\bar{l}$ ), that only the few true experts in Arabic can fully appreciate the extent of this Qur'ān's linguistic superiority, and that the Qur'ān's generic form falls outside of what was



30 These are also the only sections of the text that have been translated into English, see VON GRUNEBAUM 1950.

31 See, for example, the following sources: ABŪ MŪSĀ 1984; al-MAṬ'ANī 1985: 275-83. 
plines relates to work in the other, shedding light on al-Bāqillānī's body of work and indicating the rewards of theorizing language in his oeuvre. It provides a more complete picture of the identity of a scholar who was concerned with providing a consistent and multifaceted theory of language within a broader synthesis of Islamic thought. Through this investigation, the understandability and clarity of utterances, and particularly the Qur'ān, emerge as the central concern of his thought across the genres that this study investigates. In this way, al-Bāqillānī establishes the expressive clarity of the Qur'ān as inimitable and, at the same time, as verification of its understandability, a move that sets the practice of exegesis on stable theoretical footing. This idea emerges as a proposed resolution to the tension between views of the Qur'ān as inimitable miracle and the Qur'ān as a reliably interpretable basis for Islamic thought. I have selected three prominent examples of shared areas of discussion as focal points for this comparison: bayān, muhkam and mutashābih, and the socalled Mysterious Letters of the Qur'ān.

\section{Textual Intersections: Three Examples}

\section{Bayān}

The term bayān is the first key point of intersection in both al-Bāqillānī's $u s ̦ \bar{u} l$ and $i{ }^{\prime} \bar{a} z$ texts that I have chosen to examine. For explanatory purposes, the most straightforward rendering of the term bayan may be 'clearness' or 'distinctness.' The word is a verbal noun from the Form I verb bāna [to become clear, distinct, differentiated], whose root is B-Y-N. Edward Lane notes in his dictionary of classical Arabic that the term bayān conventionally refers to the "means by which one makes a thing [distinct,] apparent, manifest, evident, clear, plain, or perspicuous," which can either be "a thing indicating, or giving evidence of, a circumstance, or state, that is a result, or an effect, of a quality or an attribute," or the "language that discovers and shows the meaning that is intended." age, discussions of bayan are generally concerned with the clarifying ability of language and explanations in the service of understanding. Enlightening scholarship on this topic has contributed to the record of the ways ușūl scholars explained bayān, but al-Bāqillān̄̄ss work has been largely absent from this history of the term. ${ }^{33}$ The discourse on bayann in ușūl al-fiqh literature is thus a particular instance where al-Bāqillān̄’s input could enrich the scholarly discussion, given the availability of textual evidence and the context in which to understand al-Bāqillānī's contribution.

Al-Bāqillān̄̄'s work on bayān may have been largely overlooked because of the relatively recent publication of the Taqrīb (as the above references from the mid- $20^{\text {th }}$ century indicate). Even given access to this text, though, Joseph Lowry has pointed out that alBāqillānī does not delve into a discussion of bayān in the short version of the Taqrīb that we have, because he had already done so in the long version to which we unfortunately do

\section{LANE 1968: 288.}

33 Excellent articles on the history of bayān in ușūl al-fiqh include LOWRY 2008 and BERNAND 1995. A broader history of bayān can be found in VON GRUNEBAUM 2015. Each of these texts touches on alBāqillānī but does not give a detailed account of his ușūl th thought on bayān. 
not have access. ${ }^{34}$ However, Abū Zunayd's third volume of the Taqrīb does include sections on bayān that provide insight into al-Bāqillān̄̄'s views on the topic and can help us situate them in relation to other scholars' understandings of it. Al-Bāqillānī begins his discussion of bayān by providing general and technical ușūl $\bar{l}$ definitions of it. In his nontechnical definition of bayān, al-Bāqillānī cites linguists' definition of bayān as the appearance, distinction, or separation of an item. ${ }^{35}$ In this vein, al-Bāqillānī provides several examples of the term bayan and other words from the same root in non-language-related contexts, with glosses on them that show that bayān is identified with clarity, clarifying, and distinguishing. Al-Bāqillānī's technical definition of bayān is 'an indication' [dalīl], i.e. the knowledge by which we know the word's meaning: ${ }^{36}$

It is the indicant [dalill] that is connected, by sound reflection [nazar] on it, to the knowledge $[$ ilm $]$ of which it is an indicant. ${ }^{37}$

In other words, bayān is the means by which knowledge comes to be known by a thinker who reflects on and understands the indicant properly. Al-Bāqillānī continues with an extensive set of discussions about bayān that engages topics current in kalām (theology) discourse at his time. For instance, he writes that necessary knowledge does not have bayān because it is known directly. Al-Bāqillānī also responds to other scholarly opinions expressed in the same technical discourse. A prominent example is that al-Bāqillānī clarifies that unlike other ușūl scholars (such as al-Shāfi īi, not mentioned by name), he does not hold that bayān must clarify another, unclear text, but rather that its object is knowledge. ${ }^{38}$

The term bayān also arises in $i j \bar{a} z$ al-Qur'ān discourse, but in classical $i j \bar{a} z$ writings it

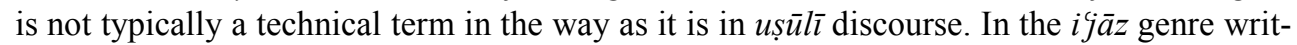
ings of al-Bāqillānī's precursors and contemporaries, the word bayān is used as part of a semantic field of words related to rhetorical excellence, such as fașāha and balägha. This point can be illustrated with reference to 'Alī ibn 'Īsa al-Rummānī (d. 998) and Abū Sulayman Hamd ibn Muhammad al-Khațāaī (d. 996), two scholars who composed books on i'jäz al-Qur'ān around the same time as al-Bāqillānī. Al-Khațtābī, in his short treatise Bayān I'jäz al-Qur'än, does not use the term bayān widely, but when he does, it is often in the general sense of 'explanation,' 'exposition,' or 'clarification,' as in the title of his book, which Issa Boullata has recently translated under the title "Elucidation of the Qur'ān's Ijāz. ${ }^{, 39} \mathrm{Al}-\mathrm{Khatt} a \bar{a} \overline{\mathrm{i}}$ responds to a potential claim from an opponent that the Qur'ān is not fully clarified (mubayyan) by responding that he has "presented the explanation [bayān] of the descriptions of rhetorical excellence [balāgha] in the Qur'ān." ${ }^{, 40}$ Al-Khatțābi also occa-

34 LOWRY 2008: 522. Al-BĀQILLĀNĪ refers to that lengthier discussion in Taqrīb, iii: 374.

35 Ibid.: $370-71$.

36 The designation of this definition as technical comes from al-Juwayn̄̄'s abridgement of the Taqrīb, entitled Talkhīṣ al-Taqrīb. Al-Juwaynī repeats this definition verbatim. Al-JUWAYNī, Talkhīṣ, ii: 20405.

37 Al-BĀQILLĀNī, Taqrīb, iii: 370.

38 Ibid.: 372-73.

39 al-KhAȚȚĀBĪ, "Elucidation of the Qur'ān's Ijāz," in the English translation (2014) of KhALAfALlĀH \& SALLĀM (eds.) 1968.

40 Al-KHAṬṬ̄̄Bī 1968: 35. 
sionally uses the word bayān to refer to general excellence of the rhetorical quality of an utterance, as when he says that the Qur'ān's expressions are "located in the most eloquent and best aspects of rhetorical excellence [bayān]. ${ }^{.41}$ In these ways, al-Khattāai uses the term bayān much as he does words like fașịh (eloquent) and balägha (excellent rhetoric) to describe the qualities of the Qur'ān's language, not distinguishing bayān as having its own unique technical signification within the semantic field of rhetorical excellence.

The body of al-Rummānī's $i$ c $j \bar{z} z$ treatise is made up of a list of ten aspects of the Qur'ān's literary inimitability, the last one of which is bayān. In that section, al-Rummānī says the entirety of the Qur'ān is classified as being beautiful bayān of the highest rank. ${ }^{42}$ He includes a definition of the term bayān: "Bayān is supplying that which makes apparent the distinction of a thing from everything else perceived." ${ }^{43}$ He posits that bayann has four parts: speech, state, indication, and sign; within this classification, speech has two types: "speech that manifests the distinction of a thing from all else, which is bayann; and speech that does not manifest the distinction of a thing from all else, which is not bayann, like mixed-up speech and impossible speech from which meaning is not understood." ${ }^{44}$ For alRummānī, the term bayān is only used for speech that expresses beautifully, not for clumsy, ugly expressions, and he provides numerous Qur'ānic verses as examples of superlative bayān. ${ }^{45}$ The distinction he draws between speech that is bayān and speech that is not recalls the larger discussion of bayān taking place beyond the realm of $i{ }^{c} \bar{a} \bar{z}$ discourse. AlRummānī does not expound on his conception of bayān and the special properties of Qur'ānic bayān that render it superior to other (human-authored) speech that manifests bayān. On this basis, a reader may conclude that al-Rummānī drew on an educated and informed conception of bayān without developing it into a technical term in the $i j \bar{a} z$ lexicon.

Al-Bāqillān̄̄'s discussion of bayān is found outside the widely-studied sections of his book described above. It is found, instead, in a vital but often overlooked section of his book where he theorizes a novel distinction between features of the Qur'ân's language and structure that have a bearing on its inimitability and those that do not. There are many conditions that al-Bāqillānī stipulates must be fulfilled for a rhetorical feature to be considered a contributor to $i j \bar{a} z$. Some rhetorical and stylistic features participate in $i j \bar{a} z$ and others do not, and al-Bāqillānī draws this distinction by giving examples of particular features in each category rather than explaining the essential difference between the categories.

One of the meta-categories of textual features where al-Bāqillānī says $i \zeta \bar{c} z$ is found is bayān. Al-Bāqillānī associates bayān with other expressive properties of language, and he is in agreement with his fellow $i$ i $\bar{a} z$ writers in generally using this term to emphasize the soundness of Qur'ānic expression. However, he is unique among classical writers on $i j \bar{a} z$ in that he developed the concept of bayān as a distinctive technical feature of the Qur'ān in his $i j \bar{a} z$ work, developing his conception of bayān much more fully than his contemporaries

\footnotetext{
41 Ibid.: 37-38.

42 Al-RummāNĪ, Nukat: 107.

43 Ibid.: 106.

44 Ibid.: 106.

45 Ibid.: 106-09.
} 
al-Rummānī or al-Khațạāī do. He does not see it merely as having an aesthetic function; rather, he emphasizes the word bayān's association with clarity and clarifying. That emphasis is one component of al-Bāqillān̄̄'s multifaceted expression of the idea that the Qurān and all sound language usage are eminently clear.

Al-Bāqillānī argues that the Qur'an contains a consistent, high level of bayān that is miraculous and inimitable. Bayān is connected to the production of understanding in a text's audience; features of this clear and clarifying bayān can be more specifically identified and associated as such with $i^{\prime} j \bar{a} z{ }^{46}$ Al-Bāqillān̄̄'s classification of features that contribute to $i^{\top} j \bar{a} z$ also includes rhyming verse endings (fawāṣil), verse breaks (maqāți), verse beginnings (mațāli), and suitable wording (talā'üm al-kalām). ${ }^{47}$ It is noteworthy that these categories are not included in al-Bāqillān̄̄'s famed chapter on $b a d \bar{\imath}^{\varsigma}$, perhaps because they are not normatively considered types of $b a d \bar{l}^{\prime}$ in taxonomies of that phenomenon. Rather, these characteristics that concern versification and word choice are semiotic features of the text, deeply implicated in the expression and communication of meaning in utterances. AlBāqillānī discusses bayān as a property of the Qur'ān's language, prooftexting the verses that say the Qur'ān is clear or clarifying. ${ }^{48}$ For al-Bāqillānī, the point of bayān overall as well as its constitutive features like isti'âra ('borrowing,' 'metaphor') is to communicate ideas clearly. In the introductory chapter, al-Bāqillānī states this thesis directly, using the root B-Y-N repeatedly in phrases such as "the Almighty clarified in it [i.e. the Qur'ān] that its proof is sufficient and guiding, and with its lucidity [wudū $h]$, not needing a clarification to exceed it." ${ }^{, 49} \mathrm{He}$ closes the chapter with Qur'ānic verses that emphasize clarity: "a Scripture whose verses are made distinct as a Qur'ān in Arabic for people who understand" [Q 41:3], ${ }^{50}$ and "We have made it a Qur'ān in Arabic so that you [people] may understand" [Q 43:3]. ${ }^{51}$ This method of prooftexting the Qur’ān through which al-Bāqillānī scripturally supports his point allows him to locate his thesis strongly in the Qur'ānic text and read his own definitions of contentious terms back into the text itself.

As a feature connected to the Qur'ān's inimitability, bayān is a characteristic of style that attests to the text's miraculousness. Elaborating the concept of bayān and explicating its properties and relationship to inimitability in this technical and highly developed way sets al-Bāqillānī apart from his peers in $i j \bar{a} z$ discourse and may be seen as a mark of the influence of his identity as a theologian and legist knowledgeable of other discourses such as $u s \underline{u} l$ where the term bayān was also used in a technical and reified way.

Despite the fact that Kitāb I'jāz al-Qur'ān and the Taqrīb examine bayān from two disparate vantage points, the conception of bayān that lies behind both is consistent. The i ${ }^{\prime} \bar{a} z$ treatise describes bayān as a feature of the Qur'ān that is consistently excellent and

\footnotetext{
46 Al-BĀQILLĀNī, Ijjāz: 429.

47 Ibid.

48 Verses declaring the Qur'ān's property of being in clear Arabic are among those most heavily cited by al-Bāqillānī in this text. Q 26:195 declares "in a clear Arabic tongue," and it is cited in al-BĀQILLĀNī, Ijāz: $12,45,298,314$, and 418.

49 Ibid.: 3.

50 Quoted in al-BĀQILLĀNī̄, Ijāaz: 9.

51 Quoted ibid.
} 
only occurs in lesser levels in human speech. This account does not suggest that an utterance that is a bayān is identified as such because it clarifies some other utterance (though it may also do that), but rather that it constitutes bayān because it communicates meanings and ideas clearly. Whereas some of al-Bāqillānī’s uṣūlì peers would identify bayān as that which clarifies a separate utterance, al-Bāqillānī disagrees, maintaining that any clear utterance (i.e., one that communicates knowledge) constitutes bayān, whether or not it requires knowledge of additional information or utterances in order to be clear to a reader or listener.

In both texts, discussions of the definition and properties of bayān are one location where al-Bāqillānī develops his emphasis on the clarity of language and the particularities of the miraculous clarity of the Qur'àn through attention to its linguistic and rhetorical properties. His ușūli discussion of bayān responds to debates in that field and asserts that bayān is an indicant through which knowledge is known, and that any utterance can be bayān, regardless of whether there is a secondary utterance that it clarifies. Analysis of his i ${ }^{i} \bar{a} z$-based discussion of bayān suggests that in that context he treated it as a clarifying feature of language that was connected to word choice and versification.

\section{Muhkam and mutashäbih}

Another significant area of overlap between the Taqrīb and I'jāz al-Qur'ān concerns the Qurānic keywords muḥkam and mutashābih. Al-Bāqillān̄̄ also weaves his strategic reinterpretation of these fraught terms into both his $i j \bar{a} z$ and $u s ̦ \bar{u} l$ work in a significant recasting of the question of interpretability. The terms muhkam and mutashābih were a key site of disputes, garnering a variety of interpretations by scholars. ${ }^{52}$ As al-Bāqillānī’s and other scholars' views on Q 3:7 have shown, this verse was a locus of scholarly debate on humans' ability to interpret the Qur'ān. ${ }^{53}$ One common interpretation of the terms muhkam and mutashābih was that muhkamāt were āyāt understood to be clear and not in need of interpretation (thus not open to alterative readings), while mutashābihāt were ambiguous verses open to multiple interpretations. According to some interpreters, these latter verses are available for interpretation by humans, while other commentators held that only God could understand such verses, and trying to understand them could mislead people. ${ }^{54}$

Al-Bāqillānī explains his own definitions of muhkam and mutashābih in both his ijāzz and $u s \underline{u} l$ texts, and his pointed ways of situating and applying these terms are consistent

52 For accounts of how a wide range of interpreters have explained these terms in Q 3:7, see KINBERG 1988, SYAMSUDDIN 1999 and MASSEY 2014. For analogies in the Shī'î tradition, see STEIGERWALD $2006 \mathrm{a} / \mathrm{b}$.

53 The verse is especially difficult to render in English due to the significant lexical and grammatical items that have served as the basis for exegetical debate. One possible translation of its meaning reads as follows: "It is [God] who has sent this Scripture down to you [Prophet]. Some of its verses are clear [or 'definite' - $\bar{a} y \bar{a} t$ muhkamāt] in meaning - these are the cornerstone of the Scripture [umm al$k i t a \bar{b}$ ] — and others are mutually similar [or 'ambiguous' — mutashābihāt]. The perverse at heart eagerly pursue the ambiguities [mā tashābaha minhu] in their attempt to make trouble and to pin down its interpretation: nobody knows the interpretation [ta'wilah $\bar{u}]$ except God and those firmly grounded in knowledge who say [or "except God. Those firmly grounded in knowledge say"-al-rāsikhūn fì ' $l$ ilm], 'We believe in it: it is all from our Lord' - only those with real perception will take heed."

54 See Syamsuddin 1999: 71-72. 
and closely aligned across these texts. He does not address Q 3:7 in a single section of either text devoted to exegesis of that verse but rather explains his conception of each of the two terms at thematically relevant points in each text. In both texts, al-Bāqillānī takes the word muhkam to have two significations: the first refers to an utterance whose meanings are expressed overtly, and the second refers to an utterance that is internally consistent and non-contradictory, either in meaning or in arrangement (structure) ${ }^{55}$ Al-Bāqillānī suggests that these terms' applicability is not limited to Qur'ānic ayyät but rather covers any utterance (kull kaläm), in a departure from the standard understandings of the scope of these terms. All language, for al-Bāqillānī, is understandable using one unified set of criteria and categories.

As for the term mutashābih, al-Bāqillānī defines it as speech that carries multiple meanings. ${ }^{56} \mathrm{He}$ thus allows for a single utterance to carry two or more meanings at once, as long as the meanings do not contradict each other. His examples clarify how this multivocality works: a word that can indicate different meanings (i.e., homonymy or polysemy) is used in an utterance that does not indicate that one of the meanings is not operable in that utterance ${ }^{57}$ His explanation is distinguished from the more normative interpretation of the word mutashābih as meaning 'ambiguous/obscure verse.' Al-Bāqillān̄̄'s proposed alternative meaning is in accordance with his turn away from the notions of linguistic vagueness and opacity. Recasting the definition mutashäbih in the way he does is one component of his rejection of the idea of a category of unclear or opaque verses in the Qur'ann. Instead, alBāqillānī pointedly casts the whole Qur'ān as understandable and clear.

It is highly unusual to include discussion of the terms muhkam and mutashābih in i'jāz al-Qur'ann writing because those topics are not strongly associated with the literary, aesthetic, or rhetorical aspects of the Quraanic miracle. On the contrary, they open up disputes about understandability and interpretability of the kind that may not unequivocally or clearly support defenses of the Qur'ān's inimitability. Al-Bāqillānī's book is the only one in this genre that includes discussion of these terms, and including this topic in Kitäb i $i \bar{a} z$ alQur'än implicitly bridges the $i{ }^{\prime} \bar{j} z$ discourse and other exegetical disciplines. As a theological move, this inclusion also suggests discussion of $i j \bar{a} z$ is part of a cohesive and consistent world of Islamic thought rather than a niche undertaking. In Kitāb i j $^{a} \bar{z}$ al-Qur'ān, alBāqillānī weaves his reading of Q 3:7's contentious terms into his assertion that the Qur'ān's level (of language use, rhetorical excellence, and clarity) does not waver at all but is consistent, so that verses are 'mutually similar' to each other in their level of clarity and excellence.

Al-Bāqillān̄̄'s creative reassignment of meanings to the terms muhkam and mutashābih, in the context of the Qur'ān's linguistic inimitability, supports his thesis that the Qur'ān's level of linguistic excellence is consistent and does not waver or fluctuate (yatafawwat) specifically with regard to its level of clarity. He argues that the Qur'ān's language usage is

55 Fa-kull kalām hādhih̄̄ sabīluhū fa-innahū yūṣaf bi-annahū muḥkam wa-in ihtamala wujūhan wa'ltabasa ma'nāhu'. Al-BĀQILLĀNī, Taqrīb, i: 330.

56 Al-BĀQILLĀNī, Taqrīb, i: 330-31.

57 Put simply, homonymy is when a single lexical item carries two or more distinct and unrelated meanings; polysemy is when a single lexical item has two or more different but related senses. However, closer study blurs the distinction between the two. LYONS 1977: 550-69. 
distinguished from that of humans because the Qurān always maintains a level of excellence that humans cannot uphold for more than a line or two. Thus, in content as well as form, the Qur'ān is consistent, unwavering, and cogent. He ties this mu'jiza (miracle) of consistency to the term muhkam, thereby asserting that this contentious term actually refers to the Qur'ān's verses' similarity to each other in terms of their level of clarity. He cites key $\bar{a} y \bar{a} t$ to support his point, as in the following passage:

The arrangement of the Qur'ān [. . .] does not vary [in quality], as [God] said: "If it had been from anyone other than God, they would have found much inconsistency in it" [Q 4:82]. It does not deviate from its uniformity [tashäbuhihī] and internal consistency [tamāthulihī] —as [God] said: "an Arabic Qur'ān without any distortion" [Q 39:28], and "a Scripture that is consistent [mutashābihan]" [Q 39:23] —and does not cease elucidating [ibānatihī], as [God] said: "in a clear Arabic tongue" [Q $26: 195]$. $^{58}$

This passage emphasizes the clarity of the Qur'ān in its entirety, leaving no room for viewing any type of verse as an exception that is clear only to God and/or the Prophet (in the way that some other scholars interpreted the word mutashābih). The prooftexting of Qur'ānic verses al-Bāqillānī does here is typical of his method across his oeuvre.

Here, al-Bāqillāni explains the term mutashābih by linking the fraught term with the word mutamäthil ('mutually similar') in a construction that suggests they are near synonyms for him. The root SH-B-H, from which the term mutashābih derives, yields words having to do with similarity and resemblance as well as doubt and confusion. ${ }^{59}$ The root of the word mutamäthil, M-TH-L, has a wide range of meanings, including those that concern likeness and comparison. ${ }^{60}$ The morphological form of both words signifies mutuality. Pairing these two terms highlights the prominent area of overlap between their respective meanings. His usage of the term mutashābih shows he interprets it to mean 'mutually similar,' supporting his view with a verse about how the Qur'ān has no discrepancies in it.

Al-Bāqillānī also links these two terms in another passage, writing about the Qur'ān that God "clarified its light, brought its path close, eased its way, and in that made it mutually similar [mutashābih], like unto itself [mutamāthil], and despite that [sustained clarity], clarified [humans'] inability to [produce] it." ${ }^{\prime \prime 1}$ Its verses support and confirm each other rather than being contradictory, as the verse says they would be if the source of the Qur'ān were not God. Even if not all verses are equally easy to explain, holding that Qur'ānic style never fluctuates allows al-Bāqillānī to demonstrate the communicative excellence of some verses and proclaim by extension that the same excellence obtains in all verses. This synecdochic understanding of eloquence underpins al-Bāqillān̄̄'s approach to the Qur'ān as a text whose very clarity is a testament to its miraculousness.

\footnotetext{
58 Al-BĀQILLĀNī, Ijāaz: 314.

59 LANE 1968: 1510.

60 LANE 1968: 3017.

61 Al-BĀQILLĀNī, Ijjāz: 69.
} 
Elsewhere, al-Bāqillānī ties this idea of internal consistency of content and level of eloquence directly to $i j \bar{a} z$. He writes, in his chapter summarizing all aspects the miracle, that the seventh aspect of the Qur'an's inimitability is as follows:

The meanings [ $\left.a^{c} \bar{a} n \bar{l}\right]$ that it includes - in [the realm of] the setting down of $\operatorname{sharit}^{-} a$ and its prescriptions, proofs of the source of religion, response to the unbelievers regarding marvelous expressions, its internal consistency [muwäfaqat ba'diha $\left.b a^{\prime} d\right]$ in subtlety and superiority [bara $\left.\bar{a}^{\prime} a\right]$ - all of these are among that which is difficult and even impossible for humans. This is because it is known that selecting wording for familiar, current ideas $\left[m a^{c} \bar{a} n \bar{l}\right]$ and associations $[a s b \bar{a} b]$ in circulation among people is easier and more accessible than selecting wording for original ideas and newly established connections. If the wording of an exalted idea is outstanding, it is finer and more amazing than when the wording is superior for a well-established, [already] conceived-of matter. When these aspects that bolster what it is originating and that it seeks to establish for the first time and affirmation is intended, relative merit in excellence and eloquence become apparent. If the wording is in agreement with ideas, and the ideas in accordance with them [i.e. the utterances], such that one of these categories is more than the other, then the excellence is more apparent and the eloquence is more perfect. ${ }^{62}$

Here, al-Bāqillānī describes the verses' tashābuh (in his sense of mutual similarity in level of clarity) using a different wording, muwāfaqat ba'dihā ba'dan ('internal consistency') which avoids the contentious term in Q 3:7 while expressing a similar idea. Meanwhile, he emphasizes the importance of the Qur'ān's speech having perfect mutual suitability of meanings and wording, thus allowing the Qur'ān to be a comprehensible basis for law. This type of explanation is one of the means by which al-Bāqillāni makes clear the ways in which $i j \bar{a} z$ fits into his larger theological project. While other $i j \bar{a} z$ scholars also locate rhetorical excellence in the combination of the superlative level of content and wording found in the Qurān, al-Bāqillānī is unique among these scholars in naming categories of content that the Qur'ān includes in this context. In particular, he lists the Qur'ān's proffering of legal and theological knowledge that, since they are understandable to humans, are available to form the basis for Islamic religious and legal thought.

Al-Bāqillānī decouples the terms muhkam and mutashābih by explaining them as categories that are not oppositional at all; in his understanding, an utterance could be both muhkam and mutashābih. He discusses the terms together (as was consistently the case in discussion of these terms), but his explanations make clear that for him they are separate categories, not opposites of one another. Being muhkam speaks to the clarity and consistency of an utterance, while the status of mutashäbih concerns multivalence. In approaching the discussion in this way, he takes his readers from an expected starting point to a new understanding of muhkam and mutashäbih as decoupled, non-oppositional terms. AlBāqillānī writes that speech fitting this description is muhkam even if it carries multiple facets (of meaning) and its meaning is obscured (ihtamala wujūhan wa-iltabasa ma'nāhu); thus an utterance can be both muhkam and mutashäbih. However, if speech's nazm is cor-

62 Al-BĀQILLĀNī̄ Ijāaz: 63. 
rupted, that speech is described as corrupt, not as having tashābuh. For al-Bāqillānī, muhkam here means clear communication, either in meaning or (grammatical) structure (naẓm wa-tartīb).

\section{The Mysterious Letters}

So far, we have seen how two very different topics, bayān and the contested pair of terms muḥkam and mutashābih, recur in al-Bāqillān̄̄'s Qur'ānically centered legal and rhetorical theories. The third example I will discuss of bridging concepts in his thought is that of the so-called Mysterious Letters ( hurüf muqațta' $a$ ). These letters are found at the beginnings of 29 süras of the Qurān and have long been a source of puzzlement and speculation for interpreters. $^{63}$ Islamic tradition has typically considered them to be mutashābihat, in the sense of opaque verses open to a multiplicity of possible interpretations, "but no definitive solution or explanation has ever risen to widespread acceptance."64 The Qurān itself often follows these letters immediately with verses proclaiming the Qur'ān's clarity, fueling speculation about their meaning. Eventually they became one of the paradigmatic instances of the category of the mutashäbih. As such, some scholars took the position of 'consignment'; that is, they viewed these verses as secrets known only to God. Others treated the mutashābihāt as being open to a multiplicity of interpretations by human audiences. However, even scholars who espoused the theory of consignment (e.g. al-Tha'labī, al-Wāhiidī, and al-Qurtubī) put forth lists of interpretations. ${ }^{65}$ Exegetes interested in defending the Qur'ān's inimitability, such as Quțrub and al-Farrā', tended to argue that the letters reinforce the idea that the Qur'ān is made of ordinary letters and yet was never matched in level by human composition. (This point feeds into a larger debate over whether the tahaddī, or challenge, to produce a süra like those in the Qur'ān necessitated the Challenge being accessible to humans. ${ }^{66}$ Al-Bāqillānī enters into this debate over the signification of the Mysterious Letters and takes the opportunity to reframe discussion of a Qur'ānic feature to support his thesis of the Qur'ān's eminent clarity, as we saw him do above in the cases of other contentious terminology.

Al-Bāqillān̄i summarizes the range of posited meanings of the hurūf muqațta'a and casts doubt on their veracity. ${ }^{67}$ He follows in the steps of scholars who considered these letters to be understandable by humans and goes further in seeing them as announcements of the Qur'ān's clarity. In the Taqrīb, al-Bāqillānī writes that the best of what has been said in the debate over the Mysterious Letters' meaning is that these letters are actually a kināya, or allusion, to the rest of the alphabet, a metonymic reference to the entirety of the Arabic letters, therefore encompassing the whole of the süra for which these letters serve as a beginning. ${ }^{68}$ However, al-Bāqillānī does not see this phenomenon as an exclusively Qurānic one. He provides some examples of poetry that he interprets to contain certain

63 NGUYEN 2012. For an overview of the topic, see MASSEY 2014.

64 NGUYEN 2012: 6.

65 Ibid.: 9.

66 See RAHMAN 1996: 415.

67 Al-BĀQILLĀNī, Taqrīb, i: 331.

68 Ibid.: $332-33$.

$J A I S \cdot 16$ (2016): 99-123 
letters that metonymically stand for the whole poem, as in the case of poems that begin a line with the word ' $a$-lā ${ }^{69}$ There are different interpretations of this particle, al-Bāqillānī says. Some people also call those usages 'Mysterious Letters,' even though they are found in human-authored compositions rather than the Qur'ān. ${ }^{70}$ Others say, on the contrary, that God put these letters at the beginning of the süras precisely because the Arabs did not have the habit of doing so, a reference to the explanation of $i j \bar{a} z$ as having broken the customs of the Arabs in speech. ${ }^{71}$ Al-Bāqillānī does not refute either of these ideas, though they may seem incompatible. However, he comments the familiarity of the letters themselves underscores "the Arabs' being informed that it [i.e., the Qur'ān] addresses them in their [own] language." 72

This interpretation is consistent with al-Bāqillānī's explanation of the Mysterious Letters in his Kitāb Ijāz al-Qur'ān, where his goal is also to recast these famously 'mysterious' elements of the Qur'ān as signs indicating the Qur'ān's clarity—self-referential announcements that serve as reminders that the Qur'ān is made up of the same letters familiar from Arabs' own speech. ${ }^{73}$ In that text, al-Bāqillānī explains that long after the time of the Prophet, experts on Arabic language independently discovered the properties of the letters of the alphabet (e.g. whether each letter is voiced or emphatic, and its place and manner of articulation), and any educated observer can witness that there are significant patterns in the occurrence of Mysterious Letters based on these properties. He writes in Kitāb Ijjāz alQur'ān:

The letters on which the Arabs' speech is based are 29 letters, and the number of süras that open with the mention of the letters is $28 .{ }^{74}$ All of the letters that are mentioned at the beginnings of süras are half of the entirety of the letters of the alphabet, which is 14 letters, in order to indicate the others by their mention, and so they may know that this speech is arranged [muntazam] from the letters with which they arrange their speech. These letters are divided according to how Arabic experts divided them and built upon them divisions by aspect, which we will mention. ${ }^{75}$

69 The implication is that $a-l \bar{a}$ does not impart a meaning in the sense that words ordinarily do but rather communicates something metapoetic or metalinguistic. Wright lists many uses for the particle $a-l \bar{a}$, the most relevant here being his characterization of it as "often used to draw close attention to the certainty of the following assertion, and hence admits being rendered into English by truly, verily, certainly" and "as a corroborative before the optative perfect, the imperative, jussive, and energetic." W. WRIGHT 1964: 310. Citations refer to the Cambridge edition.

70 Al-BĀQILLĀNī, Taqrīb, i: 334.

71 Ibid.: 334.

72 Ibid.: 333.

73 Al-BĀQILLĀNİ, Ijāaz: 68-69.

74 Al-BĀQILLĀNI seems to intend to draw an equivalence between the number of letters in the Arabic alphabet and the number of süras that open with hurüf muqața'a. He does not explain the discrepancy between the numbers, but one possible explanation is that 29 signifies 28 letters of the alphabet plus the hamza, the glottal stop that is orthographically represented in written Arabic but not named as a letter in the alphabet.

75 Al-BĀQILLĀNī, Ijāz: 66. 
According to this line of thought, affirmation of the distribution of Mysterious Letters relies on Arabic linguists' findings during the Islamic era. 'Mathematical' defenses of the Mysterious Letters have persisted in the history of exegesis, but this 'proof' might nonetheless strike readers as being based in circular reasoning, an unsatisfying demonstration of the Mysterious Letters' indication of the miracle. Regardless, this explanation positions alBāqillānī on the side of debate that views the Mysterious Letters as pointedly familiar. Accepting the idea that the Qur'ann's Mysterious Letters are akin to elements of humanauthored poetry removes them from the realm of the 'mysterious' altogether, reassigning their signification as quite the opposite: an indication of the familiarity of the text's language. Al-Bāqillānī also draws a connection between the Mysterious Letters as divine 'signs' and 'proofs' and the sūras they open containing verses about the Qur'ān as a 'sign' and 'proof' as well. ${ }^{76}$ This explanation also emphasizes the Mysterious Letters' interpretability.

The Mysterious Letters are a standard 'aspect' of Qur'ānic inimitability found in texts on that phenomenon, but it is more surprising to find explanations of this Qur'ānic feature in a text on legal theory. They are not taken to have legal content or direct implications for Islamic law, and most explanations of them did not consider this usage of the letters to be part of the framework of ordinary language, as indicated above. Thus, al-Bāqillānī's inclusion of explanations of the Mysterious Letters in the Taqrīb is exceptional. It can be seen at once as a result of al-Bāqillānī's deep and permeating attention to the ways in which Islamic disciplines can engage each other in the service of a synthesized, unified vision of Islam and the Qur'ān, and his own desire to emphasize the Qur'ān's miraculous clarity across genres.

\section{Discussion}

This cross-disciplinary study of key elements of al-Bāqillānī’s work on ușūl al-fiqh and ijāaz al-Qur'ān has brought to light interesting areas of intersection and overlap. It has shown how al-Bāqillānī used both genres to assert and advance ideas that are part and parcel of his larger contribution as a theologian. Al-Bāqillānī expresses his views on issues including language and Qur'ānic understandability in both of the discourses I have investigated, despite the different goals of the fields of $u s \underline{u} l$ and $i j \bar{a} z$. Through my examination of al-Bāqillān̄’s writings in these genres, I have drawn out his views on language and its ways of expressing and making clear, using the examples of some contentious keywords that alBāqillānī explains and uses in both texts. Al-Bāqillānī's focus on the clarity and understandability of language, particularly Qur'annic language, is a theme of his work that cuts across his oeuvre in surprising and unique ways. In both texts studied here but particularly in the Taqrīb, al-Bāqillānī often cites the authority of Arabic experts (ahl al-'arabiyya) in questions of how to interpret utterances, thus anchoring his approach in language and its nature. $^{77}$

\footnotetext{
76 Ibid.: 12-13.

77 See, for instance, al-BĀQILLĀNĪ, Taqrīb, iii: 331-333, 370-71.
} 
Kitāb Ijāz al-Qur'ān and the Taqrīb, in the course of their generically different projects, put forth the shared thesis that language is clear and its utterances are understandable given the right information, and that the Qur'an in particular is wholly understandable by humans because it uses clear language that is measurable and understandable by the same means that allow audiences to know the meanings of human-authored language. The ways in which al-Bāqillānī departs from his predecessors and peers to explain the significations of bayān, muhkam, mutashābih, and the Mysterious Letters are three instances in which alBāqillānī shows his thought to be consistent across disciplines. This focus on meanings conveyed through language orients al-Bāqillān̄̄'s contributions to both $u s ̣ u \bar{l} l$ and $i j \bar{a} z$ discourses and is a distinguishing characteristic of his body of thought. His focus on language and the way it communicates does not constitute merely a thematic study but rather a contribution to what Gregor Schwarb has in another context called "the most basic semiotic and hermeneutic questions, i.e. how God's speech signifies and how it may be understood." ${ }^{78}$ Schwarb has also shown how different discourses, particularly within ușūl-type disciplines of the $3^{\text {rd }} / 9^{\text {th }}$ and $4^{\text {th }} / 10^{\text {th }}$ centuries, were fruitful loci of exegesis in the Islamic milieu. ${ }^{79}$ This observation is a testament to the centrality of Scripture in Islamic scholarship at large during those important eras of theological and cultural development. My reading of al-Bāqillānī's texts supports that view of theological writings beyond tafsìr proper as performing an exegetical function (among other functions).

The clarity and communicativity of language, particularly Qur'annic language, is important not merely in conjunction with contentious keywords and the disciplinary debates in which they figured. Rather, interpretability is the theoretical basis for the Islamic tradition relying on commentary with the confidence of a community that has methodical and reliable means of understanding language. Al-Bāqillānī maintains that God only revealed the Qur'ān to its human audience in words known to this audience, and according to the meanings of those words that were known to them ${ }^{80}$ This position allows al-Bāqillānī to tie a correct understanding of the Qur'ann to the known methods of understanding humanauthored utterances, and specifically to the vocabulary usage of the Arabs at Muhammad's time. Confidence in understanding of Scripture is a foundation for considering interpretation of it to be trustworthy, which in turn allows for theoretically-sound development of discourses based on this interpretability.

78 SCHWARB 2007: 114.

79 Ibid.: 112-14.

80 Al-Bāqillānī writes, citing three Qur'ānic verses about clarity: “'We made it an Arabic Qur’ān' [Q 12:2], and the Almighty's saying: 'In a clear Arabic tongue' [26:195], and the Almighty's saying: 'And we have not sent a messenger except in the language of his people. . The externally apparent meanings of these verses require that all of the speech be in the Arabic that the Arabs used, and that otherwise it would have been speech not in their language." Al-BĀQILLĀNĪ, Taqrīb, i: 391. In another passage, he says: "The angel will not go to a human messenger except for in the language of the messenger, in which he has previously learned and spoken by way of conventional knowledge of its meanings and indication." [Wa-lan yu'add̄̄ al-malak ilā 'l-rasūl min al-bashar illā bi-lughat al-rasūl allatī qad

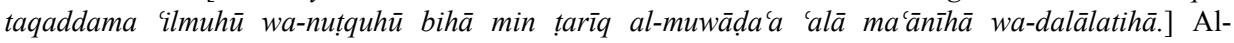
BĀQILLĀNI $\bar{I}$, Taqrīb, i: 431. For a broader discussion of the tension between the Qur'ān's addressing of all humankind and its revelation in a particular Arabic language, see KOPF 1956 and SHAH 1999. 
Taking a broader view of the significance of emphasizing clarity in this way, implications of al-Bāqillān̄̄'s thesis can be seen as amounting to more than the sum of their parts. In general, the discipline of usūl al-fiqh emphasized the Qur'ān's understandability, allowing for it to be a firm and accessible source of law. On the other hand, writings on i ijāz alQur'ān emphasized its inimitability and the miraculous qualities that rendered production of anything like it outside the realm of human capabilities. This disciplinary tension makes al-Bāqillānī's thesis of Qur’ānic clarity even more intriguing. His interdisciplinary concern for the Qur'ān's eminent clarity ultimately suggests a resolution to this tension by seeing the Qur'ān as unparalleled in its expression of excellent ideas, thereby locating both its understandability and its miraculousness in its clarity and tying those two key properties together.

\section{Conclusion}

The important insights that emerge from reading al-Bāqillānī's work in any single discipline come into clearer focus when considered in light of multiple parts of the scholar's oeuvre. A language-centered thesis might seem like one of many main ideas in his $i j \bar{a} z$ work or his $u s ̦ \bar{u} l$ al-fiqh work, but focusing on signature explanations that al-Bāqillānī includes in both of those texts - even to the point of including topics that were not conventionally treated within the genre at hand-shows that an interest in characterizing language as a basis for interpretive work cuts across his work in these disciplines. The three realms of overlap between al-Bāqillānī's ușūl al-fiqh and i ijāz al-Qur'ān treatises described here are but a few examples of this phenomenon, but many such connections occur within these books and more broadly within al-Bāqillān̄̄'s wide-ranging oeuvre.

Al-Bāqillān̄̄’s sustained cross-disciplinary concern for these topics suggests an awareness on al-Bāqillānī's part of the importance of language and its interpretation, a topic that would continue to be a source of contention. Positioning the Qurān as inherently and definitely comprehensible by humans, as al-Bāqillānī does, has important implications for theological doctrine. Perhaps most importantly, holding that the Qur'ān's human interpreters can understand its meanings strengthens the basis for the Qur'àn's status as the starting point of religious knowledge and law. If the Qur'ān were outside the realm of human comprehension, how could it be the basis of Islamic law and doctrine? How could anyone declare its words and ideas to be perfectly suited to one another if the ideas were not available to humans? Al-Bāqillānī responds to such questions by placing interpretation of the Qur'ān (in which people were already taking part) on sound theoretical footing. He reinterprets key terms to refer to verses' perfect mutual suitability of meanings, allowing the Qur'ān to be at once a comprehensible basis for law and a miraculous text. Al-Bāqillānī's scholarly identity can be described as that of a systematizer attuned to the ways in which discourses interact to produce a cohesive vision of Islamic theology. By arguing and prooftexting the idea that the whole Qurāan is subject to sound interpretation by humans, al-Bāqillānī provides a textual basis for basing Islamic law and doctrine on the Qur’ān. Even if al-Bāqillānī’s arguments are sometimes circular and his textual interpretations may not strike the reader as ultimately convincing, his awareness of a need to place Islamic exegetical and interpretive methods on solid footing and to provide a theoretical grounding for these activities speaks 
to a strategic need at this point of crystallization of traditions in Islamic religious and intellectual history.

Highlighting the Qur'ān's clarity and constructing a multifaceted explanation of it affords interpreters and their activities a place in the religious and intellectual life of the community. Describing the Qur'ān as wholly clear and understandable to human interpreters legitimizes the communities of readers who base Islamic thought on the text. The miracle of the Qur'ān is available directly to every generation, and the guarantee that it has been faithfully transmitted (an idea al-Bāqillānī defends in Kitāb Ijā̄z al-Qur'ān) is another way of defending the direct access every audience has to the text. In this way, al-Bāqillānī avoids the issue of authenticity that has defined the corpus of ahāith (Prophetic reports). ${ }^{81}$ Even aside from the particularly fraught discourse of the authenticity of ahādith, the focus on the directly-available Qur'anic text in all its clarity responds to the threat of misinterpretation by dismissing what Travis Zadeh has called "anxieties of mediation." 82 The Qur'ān is clear, so it is not in need of mediation in forms such as translation or decoding. Even in the case of parts of the Qur'ān whose eloquence and logic is more difficult for human audiences to explain, the clarity of these verses is still known and thus they are still understandable. In this way, al-Bāqillānī opens up a space between understanding and explanation. Verses whose verbal explanation is more out of reach are still part of the whole of the Qur'ann, which as an entirety can rely on metonymies to point to its clarity. The so-called Mysterious Letters are, for al-Bāqillānī, a form of metonymy that indicates the clarity of the whole text by announcing and reminding that the Qur'ān is made up of familiar Arabic letters.

This clarity is balanced out by the limits of Arabic language knowledge. Emphasizing the Qur'ān's Arabicness, and its particular usages that are tied to the Prophet's community's own usages, also determines the type of interpretive community al-Bāqillānī allows. The interpreter must be an expert of Arabic, knowledgeable about the meanings that words, structures, and idioms had at the Prophet's time. At al-Bāqillān̄̄'s time, the Islamic empire was changing in response to its recent expansion to include powerful contingents who were not native speakers of Arabic, especially in Khurasan and Transoxania. Most immediately for al-Bāqillān̄̄, the Buyid rulership of Baghdad at his time was non-Arab in origin, descendants of Zoroastrian converts to Islam from the region of Fars, probably Daylamites. During this same time, translation and exegesis of the Qur'ān in other languages were gaining legitimacy in some circles, provoking a reaction from those scholars who maintained the cultural and religious priority of Arabic. ${ }^{83}$ Suggesting that sound knowledge of the Qur'ān's meanings relied on methodical and language-based exegesis limits the community of legitimate interpreters to those with deep knowledge of Arabic. Al-Bāqillān̄̄'s continual recourse to experts of language and literary criticism grounds his understanding of the Qurān in its Arabic heritage.

Al-Bāqillānī's concern for language and its communicative nature, as well as the importance of its rhetorical and literary dimensions, privileges a larger theological vision over the practices of understanding and interpreting language. His participation in many disci-

81 For an analysis of approaches to the authenticity of ahādīth, see BERG 2000.

82 ZADEH 2007: 612.

83 ZADEH 2007: 52-59. 
plines and interest in synthesizing results in a unified and consistent theological vision expressed over multiple genres of his writing, though some interesting tensions remain unresolved. Al-Bāqillānī was an intellectual precursor to literary critics, legists, and theologians that academic consensus has deemed to be some of the greatest thinkers in Islamic history and in their respective disciplines. His wide-ranging texts must be read together in order to take full account of his contribution to Islamic thought. The surprising areas of overlap between al-Bāqillānī's $u s ̣ u \bar{l}$ al-fiqh and $i$ 'jāz al-Qur'ān treatises suggests that interdisciplinary investigations of classical-era Islamic thought can shed light on important intersections in currents of thought as well as thinkers' concerns that transcend disciplinary boundaries.

\section{Bibliography}

ABDUl AlEEM. 1933. “'Ijazu'l-Qur'an.” Islamic Culture, 7/1: 64-82.

ABū Mūsā, Muḥammad Muḥammad 1984. Al-Ijāaz al-Balāghī: Dirāsa tahlīilyya li-turāth ahl al-ilm. Cairo: Maktabat Wahba.

BĀQILlĀNī, Abū Bakr al-. Ikfār al-muta'awwilīn. Cairo: Ma'had al-Makhțūțāt al-'Arabiyya, 2006.

—. Al-Inșāf fì-mā yajib al-itiqāe wa-lā yajūz al-jahl bihī. Edited by Muhammad Zāhid al-KAWTHARĪ. Cairo: Mu'assasat al-Khānjī, 1963.

-. Al-Intișār lil-Qur'ān. 1) Edited by 'Umar Ḥasan al-QAYYĀM. 2 vols. Beirut: Mu’assasat al-Risāla, 2004; 2) edited by Muḥammad 'Ișām al-Qup̣̄̄T. 2 vols. Beirut: Dār Ibn Ḥazm, 2001.

- Kitāb al-Bayān 'an al-farq bayn al-mu'jizāt wa'l-karāmāt wa'l-hiyal wa'l-kahāna wa'l-șihr wa'lnārinjāt. Translated by Richard Joseph MCCARTHY as Miracle and Magic = Kitāb al-Bayān: A Treatise on the Nature of the Apologetic Miracle and Its Differentiation from Charisms, Trickery, Divination, Magic and Spells. Beirut: Librairie Orientale, 1958.

— . Kitāb Ijāzz al-Qur'ān. Edited by al-Sayyid Aḥmad ȘAQR. Cairo: Dār al-Macārif bi-Miṣr, n.d.

- Manāqib al-a'imma al-arba'a. Edited by Samīra FARAH̄̄en. N.p.: Dār al-Muntakhab al-'Arabī, 2002.

—. Nukat al-intișār li-naql al-Qur'ān. Edited by Maḥmūd Zaghlūl SALLĀM. Alexandria: Munsha’āt al-Ma'āif, [1971?].

—. Al-Taqrīb wa'l-irshād (al-șaghīr). 3 vols. Edited by 'Abd al-Ḥamīd b. 'Alī ABū ZunAYD. 1993. Reprint, Beirut: Mu'assasat al-Risāla, 1998.

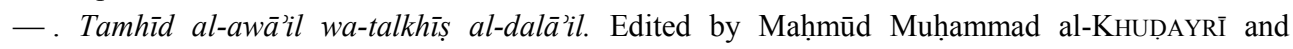
Muḥammad 'Abd al-Hādi Maḥmūd ABŪ Riḍ̄̄. Cairo: Dār al-Fikr al-'Arabī, [1989?].

Bar-Asher, Meir M. / Hopkins, Simon / Stroumsa, Sarah / ChiesA, Bruno (eds.). 2007. A Word Fitly Spoken: Studies in Medieval Exegesis of the Hebrew Bible and the Qur'ān Presented to Haggai Ben-Shammai. Jerusalem: Ben Zvi Institute.

BERNAND, Marie. 1995. "Bayān selon les ușūliyyūn.” Arabica, 32: 145-60.

BERG, Herbert 2000. The Development of Exegesis in Early Islam: The Authenticity of Muslim Literature from the Formative Period. Surrey: Routledge Curzon.

Bouman, Johan. 1959. Le Conflit autour du Qur'ān et la Solution d'al-Bāqillānī. Amsterdam: Drukkerij en Uitgeverij Jacob van Campen.

$E I^{2}=$ Encyclopaedia of Islam, $2^{\text {nd }}$ ed., edited by P. Bearman [et al.]. Brill Online. $<$ http:// referenceworks.brillonline.com>. 
El Shamsy, Ahmed. 2013. The Canonization of Islamic Law: A Social and Intellectual History. Cambridge: Cambridge University Press.

$E Q=$ Encyclopaedia of the Qur'ān, edited by Jane Dammen McAuliffe. Brill Online. $<$ http://referenceworks.brillonline.com>.

FRIEDMAN, Rachel. 2015. "Clarity, Communication, and Understandability: Theorizing Language in al-Bāqillān̄̄'s Ijāz al-Qur'ān and Ușūl al-Fiqh Texts." PhD diss., University of California, Berkeley. ProQuest Order No. 3733360. <http://gradworks.umi.com/37/33/3733360.html>.

Gimaret, Daniel. 2009. "Un Extrait de la Hidāya d'Abū Bakr al-Bāqillānī: Le Kitāb at-Tawallud, réfutation de la thèse mu'tazilite de la génération des actes." Bulletin d'études orientales, 58: 259-313.

GLEAVE, Robert. 2012. Islam and Literalism: Literal Meaning and Interpretation in Islamic Legal Theory. Edinburgh: Edinburgh University Press.

HEINRICHS, Wolfhart. 1977. The Hand of the Northwind: Opinions on Metaphor and the Early Meaning of Isti 'âra in Arabic Poetics. Mainz: Deutsche Morgenländische Gesellschaft.

—. 1984a. "On the Genesis of the Haqīqa-Majāz Dichotomy." Studia Islamica, 59: 111-140.

- 1984b. "Isti ārah and Badī' and Their Terminological Relationship in Early Arabic Literary Criticism," Zeitschrift für Geschichte der Arabisch-Islamischen Wissenschaften, 1: 180-211.

HitTI, Philip K. 1952. Review of A Tenth-Century Document of Arabic Literary Theory and Criticism: The Sections on Poetry of al-Bāqillāni's Ijāz al-Qur'ān, by Gustave E. von Grunebaum. The Journal of Religion, 32/2: 146.

IBISH, Yusuf. 1965. "Life and Works of al-Bāqillānī." Islamic Studies, 4/3: 225-36.

'IYĀḌ B. MŪSĀ. [n.d.] Tartīb al-madārik wa-taqrīb al-masālik li-ma'rifat a lām madhhab Mālik. Edited by Ahmmad Bakīr MAHMŪD. Vol. 3. Beirut: Dār Maktabat al-Hayāt.

JuRJāNī, 'Abd al-Qāhir al-. Asrār al-balāgha, ed. Maḥmūd Muḥammad ShĀKIR. Cairo: Dār alMadanī bi-Jidda, 1991.

— . Dalāi il al-i jāzz, ed. Maḥmūd Muḥammad SHĀKIR. Beirut: Dār al-Kitāb al-'Arabī, 1995.

JuwAYNī, 'Abd al-Malik b. 'Abd Allāh al-. 1996. Kitāb al-Talkhīṣ fì ușūl al-fiqh. Edited by 'Abd Allāh Jawlam NīBĀLĪ and Shubbayr Aḥmad 'UMARĪ. 3 vols. Beirut: Dār al-Bashāìr al-Islāmiyya.

Key, Alexander. 2012. "A Linguistic Frame of Mind: ar-Rāghib al-Ișfahān̄̄ and What It Meant to Be Ambiguous.” PhD diss., Harvard University. ProQuest Order No. 3514471. <http://gradworks. umi.com/35/14/3514471.html>.

Khalaf AllāH, Muḥammad / Sallām, Muḥammad Zaghlūl (eds.). 1968: Thalāth rasāìl fì i jā̃z alQur'ān. Cairo: Dār al-Ma'ārif. - Translated into English as Three Treatises on the Ijāz of the Qur'ān: Qur'ānic Studies and Literary Criticism, trans. Issa J. BoullatA, Reading, UK: Garnet Publishing Ltd., 2014.

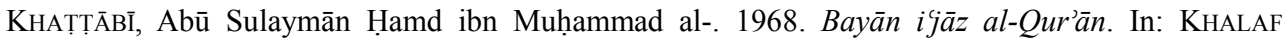
AllāH \& SAllām (eds.) 1968: 19-65.

KINBERG, Leah. 1988 "Muhkamāt and Mutashābihāt (Koran 3/7): Implication of a Koranic Pair of Terms in Medieval Exegesis." Arabica, 37/2: 143-72.

Kopf, L. 1956. "Religious Influences on Medieval Arabic Philology." Studia Islamica, 5: 33-59.

Lane, Edward W. 1968. An Arabic-English Lexicon. 2 vols. [1863-.] Reprint, Beirut: Librarie du Liban.

LARKIN, Margaret. 1995. The Theology of Meaning: 'Abd al-Qāhir al-Jurjānī's Theory of Discourse. New Haven, CT: American Oriental Society.

— . 1988. "The Inimitability of the Qur'an: Two Perspectives". Religion and Literature, 20/1: 31-47. 
Lowry, Joseph E. 2008. "Some Preliminary Observations on al-Šăfí̄̄ and Later Ușül al-Fiqh: The Case of the Term bayān." Arabica, 5/5-6: 505-27.

LuCAS, Scott C. 2004. Constructive Critics, Hadìth Literature, and the Articulation of Sunnì Islam. Leiden: Brill.

LyONS, John. 1977. Semantics, vol. 2. Cambridge: Cambridge University Press.

MAṬ'ANĪ, 'Abd al-'Aẓ̄m Ibrāhīm al-. 1985. Al-Majāz fì 'l-lugha wa-fì 'l-Qur'ān al-karīm bayna mujawwizìhi wa-māni îhi: 'arḍ wa-taḥlīl wa-naqd, vol. 1. Cairo: Maktabat Wahba.

MASSEY, Keith. 2014. "Mysterious Letters.” In: EQ, <http://referenceworks.brillonline.com/entries/ encyclopaedia-of-the-quran/mysterious-letters-EQCOM_00128>.

NGUYEN, Martin. 2012. "Exegesis of the Hurūf al-Muqațta'a: Polyvalency in Sunnī Traditions of Qur’ānic Interpretation.” Journal of Qur'ānic Studies, 14/2: 1-28.

RAHMAN, Yusuf. 1996. "The Miraculous Nature of Muslim Scripture: A Study of 'Abd al-Jabbār's 'I'jāz al-Qur'ān'.” Islamic Studies, 35/4: 409-24.

Rummānī, Abū al-Ḥasan 'Alī ibn 'Īsa al-. 1968. al-Nukat fí I'jāz al-Qur'ān. In: Khalaf AllāH \& SALLĀM (eds.) 1968: 69-104.

SCHMidTKE, Sabine. 2011. "Early Aš́arite Theology: Abū Bakr al-Bāqillānī (d. 403/1013) and His 'Hidāyat al-mustaršidīn'." Bulletin d'études orientales, 60: 39-71.

SCHWARB, Gregor 2007. "Capturing the Meanings of God's Speech: The Relevance of Ușül al-Fiqh to an Understanding of Ușūl al-Tafsìr in Jewish and Muslim Kalām". In: BAR-ASHER (et al., eds.) 2007: *111-*156.

SHAH, Mustafa. 1999. "The Philological Endeavours of the Early Arabic Linguists: Theological Implications of the Tawqîf-Iștilāh Antithesis and the Majāz Controversy - Part I." Journal of Qur'anic Studies, 1/1: 27-46.

Steigerwald, Diana. 2006a. "Ismā̄îlī Ta'wīl." In: The Blackwell Companion to the Qur'ān, edited by Andrew Rippin, 386-400. Oxford: Blackwell Publishing.

— . 2006b. "Twelver Shī̄ī Ta'wīl." In: The Blackwell Companion to the Qur'ān, edited by Andrew Rippin, 373-85. Oxford: Blackwell Publishing.

SyAMSUDDIN, Sahiron. 1999. "Muhkam and Mutashābih: An Analytical Study of al-Ṭabarī’s and alZamakhsharī’s Interpretations of Q. 3:7.” Journal of Qur'ānic Studies, 1/1: 63-79.

VASALOU, Sophia. 2002. "The Miraculous Eloquence of the Qur'ān: General Trajectories and Individual Approaches.” Journal of Qur'ānic Studies, 4/2: 23-53.

VERSTEEGH, Kees. 1993. Arabic Grammar and Qur'ānic Exegesis in Early Islam. Leiden: Brill.

— . 1997. Landmarks in Linguistic Thought III: The Arabic Linguistic Tradition. London: Routledge.

VishanofF, David. 2011. The Formation of Islamic Hermeneutics: How Sunni Legal Theorists Imagined a Revealed Law. New Haven: American Oriental Society.

von Grunebaum, Gustav. E. 1941. "Arabic Literary Criticism in the 10th Century A. D." Journal of the American Oriental Society, 61/1: 51-57.

- 1950. A Tenth-Century Document of Arabic Literary Theory and Criticism: The Sections on Poetry of al-Bāqillān̄̄'s Ijāz al-Qur'ān Translated and Annotated. Chicago: University of Chicago Press.

— . 2015. "Bayān". In: $E I^{2}$, i. <http://referenceworks.brillonline.com/entries/encyclopaedia-of-islam2/bayan-SIM_1298>.

WeIss, Bernard. 1992. The Search for God's Law: Islamic Jurisprudence in the Writings of Sayf alDin al-Amidi. Salt Lake City: University of Utah Press. 
Wright, William. 1964. A Grammar of the Arabic Language: Translated from the German of Caspari and Edited with Numerous Additions and Corrections, $3^{\text {rd }}$ ed. Vol. 2. Revised by W. Robertson SMith and M. J. DE GoEJE. Cambridge: Cambridge University Press.

ZADEH, Travis. 2007. "Translation, Geography, and the Divine Word: Mediating Frontiers in PreModern Islam.” PhD diss., Harvard University. ProQuest Order No. 3265135. < http://gradworks. umi.com/32/65/3265135.html>.

ZAKī, Anas. 2012. "Iktishāf makhṭūta nādira lil-Bāqillānī fì Miṣr" [Discovery of a rare manuscript of al-Bāqillān̄̄'s in Egypt]. <http://www.aljazeera.net/news/cultureandart/2012/9/24/ اكتشاف_مخطوطة_نادرة-للباقلاني-بمصر. Accessed September 15, 2015.

(C) Rachel Anne Friedman, Williams College, Williamstown, USA

\raf2@williams.edu 